\title{
Genomic Heterogeneity of the Genus Nitrobacter
}

\author{
E. NAVARRO, ${ }^{1 *}$ M. P. FERNANDEZ, ${ }^{1}$ F. GRIMONT, ${ }^{2}$ A. CLAYS-JOSSERAND, ${ }^{1}$ AND R. BARDIN ${ }^{1}$ \\ Laboratoire d'Ecologie Microbienne, Université Claude Bernard Lyon 1, F-69622 Villeurbanne Cedex, ${ }^{1}$ \\ and Unité des Entérobactéries, Institut National de la Santé et de la Recherche \\ Médicale Unité 199, Institut Pasteur, F-75724 Paris Cedex 15, ${ }^{2}$ France
}

\begin{abstract}
The genomic diversity among 22 Nitrobacter strains was investigated by determining rRNA gene restriction patterns, DNA hybridization characteristics, and DNA base compositions. The guanine-plus-cytosine contents of the DNAs ranged from 58 to 61 mol\%. As determined by DNA hybridization (S1 nuclease method), five DNA genomic groups were differentiated, and these groups formed three genomic species. Genomic species 1, which corresponded to Nitrobacter winogradskyi, was split into three subspecies. Subspecies 1a contained strain W (= ATCC 25391), the type strain of $N$. winogradskyi; subspecies $1 \mathrm{~b}$ contained proposed reference strain 6R; and subspecies 1c contained a strain of "Nitrobacter agilis" (strain ATCC 14123). Genomic species 2, which has not been described previously and which contained proposed reference strain $L L$ and four strains that were isolated from lake sediments, was distinct from $N$. winogradskyi and Nitrobacter hamburgensis. This species is not named in this paper since it could not be differentiated from $N$. winogradskyi and $N$. hamburgensis on the basis of phenotypic characteristics. Genomic species 3 corresponded to $N$. hamburgensis and was distantly related to the other genomic species.
\end{abstract}

Nitrification, the conversion of ammonium to nitrite and nitrate, is a key step in the nitrogen cycle. This process has been implicated in the supply of nitrate as a nitrogen source for plants and as a substrate for denitrification. Furthermore, it is of great importance in eutrophization and lixiviation. Therefore, nitrification is of fundamental importance in all ecosystems. Chemolithoautotrophic nitrifiers appear to be present in every environment in which nitrogen mineralization takes place (3).

Although nitrite-oxidizing bacteria were first isolated a long time ago (49), nitrification has been studied essentially as a chemical process, and the microbial populations involved have been studied only slightly (29). The reasons for this neglect are the common physiological characteristics of these autotrophic organisms, including their very slow growth rates ( $8 \mathrm{~h}$ to several days) (45) and their low growth yields $(13,52)$. These characteristics result in experimental difficulties in isolation, enumeration, and determination of specific activities (33) and hamper ecological and population dynamics studies of nitrite oxidizers $(3,23,51)$.

So far, all of the bacteria from soil and freshwater that are able to complete the second step in autotrophic nitrification (i.e., the oxidation of nitrite to nitrate) have been placed in the genus Nitrobacter (45). Currently, the taxonomy of this genus is based primarily on morphological characteristics, and for a long time the existence of one or two species (Nitrobacter winogradskyi and "Nitrobacter agilis") has been discussed $(7,44)$. In Bergey's Manual of Determinative Bacteriology, 8th ed. (44), only one species, $N$. winogradskyi, was mentioned.

A century after the first isolation of nitrite-oxidizing bacteria (49), the taxonomy of the genus Nitrobacter has begun to be clarified. Recent investigations in which DNA-DNA hybridization was used have indicated the existence of new species, Nitrobacter hamburgensis $(6,45)$ and "Nitrobacter vulgaris" (5). These two species are phenotypically different from $N$. winogradskyi in some ways; for instance, they grow faster under chemoorganotrophic conditions than under chemolithotrophic conditions. In addition, " $N$. vulgaris" is

\footnotetext{
* Corresponding author.
}

able to grow anaerobically by denitrification (12). Studies on the phylogeny of the genus Nitrobacter have indicated that this taxon is closely related to Rhodopseudomonas palustris (35), which is member of the alpha subdivision of the Proteobacteria. (41, 50).

Currently, serotyping is the reference method that is used for characterizing Nitrobacter isolates $(5,11,21,42)$. However, the subjectivity of the immunofluorescence technique hampers comparisons of results from different laboratories. Thus, other characterization methods are necessary.

In this work, we examined the genetic diversity of 22 Nitrobacter strains by using DNA base composition, DNADNA hybridization, and rRNA gene polymorphism and compared the results with results obtained by using serotyping. On the basis of our results we delineated three genomic species and split genomic species 1 into three genomic subspecies.

\section{MATERIALS AND METHODS}

Bacterial strains. The bacterial strains which we studied are listed in Table 1 . New isolates were obtained by using the petri dish isolation method (39) and were identified on the basis of their physiological properties and by using electron microscopy (21).

$N$. winogradskyi and Nitrobacter sp. strains were cultivated in 2-liter Erlenmeyer flasks containing $800 \mathrm{ml}$ of mineral medium supplemented with $2 \mathrm{~g}$ of $\mathrm{NaNO}_{2}$ per liter (34). $N$. hamburgensis $\mathrm{X} 14^{\mathrm{T}}$ ( $\mathrm{T}=$ type strain) was grown under mixotrophic conditions (6). The cultures were incubated at $28^{\circ} \mathrm{C}$, and the purity of each culture was checked by spreading samples onto nutrient broth agar (Biomérieux, Marcy l'Etoile, France).

Serotyping. The procedure described by Josserand and Bardin (20) was used for immunological studies of Nitrobacter strains. Immunofluorescence tests were interpreted by using previously published recommendations $(4,31)$.

DNA extraction. DNA was extracted and purified by using the procedure of Brenner et al. (8), with the following modification: $1 \mathrm{mg}$ of achromopeptidase (Walko Pure Chemical, Dallas, Tex.) per ml was added to the lysis solution to improve DNA extraction (36). 
TABLE 1. Origins of the Nitrobacter strains tested

\begin{tabular}{|c|c|c|c|}
\hline Strain $^{a}$ & $\begin{array}{l}\text { Other } \\
\text { desig- } \\
\text { nation }\end{array}$ & Origin & $\begin{array}{l}\text { Refer- } \\
\text { ence }\end{array}$ \\
\hline \multicolumn{4}{|l|}{ N. winogradskyi } \\
\hline $\begin{array}{c}\mathrm{W}^{\mathrm{T}}(=\text { ATCC } \\
\left.25391^{\mathrm{T}}\right)^{b}\end{array}$ & & Unknown & 37 \\
\hline B1 & & Unknown & 38 \\
\hline $\begin{array}{l}\text { "N. agilis" } \\
\text { ATCC } 14123\end{array}$ & AG & Unknown & 43 \\
\hline $\begin{array}{l}\text { N. hamburgen- } \\
\text { sis } \mathrm{X} 14^{\mathrm{T}}\end{array}$ & & Soil, Hamburg, Germany & 5 \\
\hline \multicolumn{4}{|l|}{ Nitrobacter spp. } \\
\hline LL & $\mathrm{L}$ & Soil, Lyons, France & 20 \\
\hline WBD1 & & Soil, Isère, France & 25 \\
\hline WM1 & & Soil, Montpellier, France & 25 \\
\hline LM1 & & Soil, Montpellier, France & 25 \\
\hline LM2 & & Soil, Montpellier, France & 25 \\
\hline $6 \mathrm{R}$ & & Soil, Rothamsted, United Kingdom & 36 \\
\hline DE2 & & Lake water, Dombes, France & 25 \\
\hline DE3 & & Lake water, Dombes, France & 25 \\
\hline DE10 & & Lake water, Dombes, France & 25 \\
\hline DE11 & & Lake water, Dombes, France & 25 \\
\hline DE23 & & Lake water, Dombes, France & 25 \\
\hline DE30 & & Lake water, Dombes, France & 25 \\
\hline DS13 & & Lake sediments, Dombes, France & 25 \\
\hline DS17 & & Lake sediments, Dombes, France & 25 \\
\hline DS27 & & Lake sediments, Dombes, France & 25 \\
\hline DS28 & & Lake sediments, Dombes, France & 25 \\
\hline DS30 & & Lake sediments, Dombes, France & 25 \\
\hline DS'16 & & Lake sediments, Dombes, France & 25 \\
\hline
\end{tabular}

${ }^{a}$ The strains are in the culture collection of the Laboratoire d'Ecologie Microbienne, Lyons, France, or were supplied by E. L. Schmidt (St. Paul, Minn.) or E. Bock (Hamburg, Germany).

${ }^{b}$ ATCC, American Type Culture Collection.

Gel electrophoresis of endonuclease-cleaved DNAs. Bacterial DNAs ( 2 to $5 \mu \mathrm{g}$ ) were cleaved by using restriction endonucleases $E c o$ RV and $M l u I$ (5 to $15 \mathrm{U} / \mu \mathrm{g}$ of DNA) according to the instructions of the manufacturer (Appligène, Illkirch, France). The preparations were digested at $37^{\circ} \mathrm{C}$ for $5 \mathrm{~h}$. Restriction fragments were separated by horizontal electrophoresis for $16 \mathrm{~h}$ at $2 \mathrm{~V} / \mathrm{cm}$, using a $0.8 \%$ (wt/vol) gel in Tris-borate buffer $(89 \mathrm{mM}$ Tris, $2.5 \mathrm{mM}$ EDTA, $89 \mathrm{mM} \mathrm{H}_{3} \mathrm{BO}_{3}$ ).

Determination of base composition. The average guanineplus-cytosine $(\mathrm{G}+\mathrm{C})$ content of a DNA was determined by using the chromatographic method of Peyret et al. (28). The Merck-Hitachi chromatography system used for quantification of nucleotides included a pump (model L-6200), a UV detector (model L-4000) linked to an integrator (model D-2500), and a 7- $\mu \mathrm{m}$ type RP18 chromatography column (catalog no. 15539); the mobile phase was $0.6 \mathrm{M} \mathrm{NH}_{4} \mathrm{H}_{2} \mathrm{PO}_{4}$ (pH 4.25), the flow rate was $1.0 \mathrm{ml} / \mathrm{min}$, and absorption was recorded at $260 \mathrm{~nm}$.

DNA-DNA hybridization. Native DNA was labeled by nick translation (30) with tritium-labeled nucleotides (Amersham International, Amersham, England). Levels of DNA relatedness were determined by using the $\mathrm{S} 1$ nuclease-trichloroacetic method (18). DNA-DNA hybridization tests were carried out at $70^{\circ} \mathrm{C}$ by using labeled DNAs from strains $\mathrm{W}^{\mathrm{T}}$, LL, AG, DE30, DS27, and X14 ${ }^{\mathrm{T}}$ as probes.

Thermal stability of duplexes. The thermal denaturation midpoint $\left(T_{m}\right)$ (the temperature at which $50 \%$ of the reassociated DNA become hydrolyzable by $\mathrm{S} 1$ nuclease) was determined by using the method of Crosa et al. (9), with slight modifications (10). The $\Delta T_{m}$ was the difference between the $T_{m}$ of the homoduplex and the $T_{m}$ of the heteroduplex.

Radioactive labeling of RNA. 16+23S rRNA from Escherichia coli (Boehringer Mannheim France S. A., Neylan, France) was end-labeled by using $\left[\gamma-{ }^{32} \mathrm{P}\right]$ ATP (Amersham) and a $5^{\prime}$ DNA terminus labeling kit along with T4 polynucleotide kinase (Bethesda Research Laboratories, Gaithersburg, Md.); to do this, we used the exchange reaction procedure and instructions provided by the manufacturer.

Southern transfer and hybridization. The exact procedures which we used to transfer DNA fragments to Hybond-N nylon membranes (Amersham) and for prehybridization, hybridization with labeled rRNA at $65^{\circ} \mathrm{C}$ for $17 \mathrm{~h}$, washing, and autoradiography have been described previously (15).

DNA fragment size determination. The DNA fragment size marker which we used was DNA from Xenorhabdus sp. strain 278 cleaved with $E c o$ RI. The rRNA gene restriction pattern of this DNA contained 15 fragments $(13.1,11.6,10.1$, $8.5,5.8,4.6,3.8,2.9,2.6,2.4,2.2,2.1,1.5,1.4$, and $0.8 \mathrm{~kb}$ ) (14a). Fragment sizes were interpolated by using the algorithm of Schaffer and Sederoff $(19,32)$.

\section{RESULTS}

G + C contents of DNAs. The $\mathrm{G}+\mathrm{C}$ contents of the Nitrobacter strains ranged from 58 to $61 \mathrm{~mol} \%$ (Table 2).

DNA-DNA hybridizations. The unstandardized reassociation values for homoduplexes ranged from 75 to $100 \%$. The levels of reassociation in control tubes containing only labeled DNAs ranged from 3 to $7 \%$. The $T_{m}$ values of homoduplexes (in $0.2 \mathrm{M} \mathrm{NaCl}$ ) ranged from 88 to $93.4^{\circ} \mathrm{C}$; this corresponded to 93 to $98.4^{\circ} \mathrm{C}$ in $0.042 \mathrm{M} \mathrm{NaCl}$.

The percentages of relative DNA homology at $70^{\circ} \mathrm{C}$ with reference DNAs from strains $\mathbf{W}^{\mathrm{T}}, \mathrm{AG}, \mathrm{DE} 30, \mathrm{DS} 27, \mathrm{LL}$, and $\mathrm{X} 14^{\mathrm{T}}$ are shown in Table 2 for 22 strains. These strains fell into five discrete DNA relatedness groups. Group 1a contained eight strains that were 71 to $88 \%$ related to strain $\mathrm{W}^{\mathrm{T}}$ and exhibited low levels of divergence $\left(\Delta T_{m}\right.$, about $\left.1^{\circ} \mathrm{C}\right)$. Group $1 \mathrm{~b}$ contained seven strains that were more than 90 and $86 \%$ related to strains DE30 and DS27, respectively; these strains were 47 to $67 \%$ related to genomic group la strains, with $\Delta T_{m}$ values between 4 and $6^{\circ} \mathrm{C}$. Strain AG was 53 to $59 \%$ related to group 1a strains, with $\Delta T_{m}$ values between 3 and $5^{\circ} \mathrm{C}$, and 49 to $62 \%$ related to group $1 \mathrm{~b}$ strains, with $\Delta T_{m}$ values between 4.5 and $5^{\circ} \mathrm{C}$. Strain $\mathrm{AG}$ was the only representative of group $1 \mathrm{c}$. The $\Delta T_{m}$ values among group $1 \mathrm{a}, 1 \mathrm{~b}$, and 1c strains ranged from 3 to $6^{\circ} \mathrm{C}$ (most often 4 to $5^{\circ} \mathrm{C}$ ). Thus, groups 1a, 1b, and $1 \mathrm{c}$ belonged to a single genomic species (genomic species 1) (17). Group 2 contained five strains that were 62 to $73 \%$ related to strain $\mathrm{LL}$, with a $\Delta T_{m}$ value of $3^{\circ} \mathrm{C}$; these strains were 31 to $47 \%$ related to the other genomic groups, with $\Delta T_{m}$ values of more than $8^{\circ} \mathrm{C}$. Thus, strains in this group constituted genomic species 2 . Strain $X 14^{\mathrm{T}}$, which belonged to group 3 , yielded low relative binding ratios (less than $30 \%$ ) with members of the other genomic groups; this strain was the only representative of genomic species 3 .

rRNA gene restriction patterns. The diverse patterns obtained after digestion with $M l u I$ or EcoRV are shown in Fig. 1. Actual results obtained for some strains are shown in Fig. 2. Six rRNA gene restriction patterns (patterns M1 to M6) and four rRNA gene restriction patterns (patterns E1 to E4) were obtained with MluI and EcoRV, respectively (Fig. 1). Each pattern contained one or two fragments, whose sizes ranged from 2 to $13 \mathrm{~kb}(M l u \mathrm{I})$ or from 6.1 to $19 \mathrm{~kb}(E c o \mathrm{RV})$. 
TABLE 2. Levels of DNA relatedness among strains of Nitrobacter species

\begin{tabular}{|c|c|c|c|c|c|c|c|}
\hline \multirow{2}{*}{ Source of unlabeled DNA } & \multirow{2}{*}{$\begin{array}{l}\mathrm{G}+\mathrm{C} \\
\text { content } \\
(\mathrm{mol} \%)\end{array}$} & \multicolumn{6}{|c|}{$\%$ Reassociation at $70^{\circ} \mathrm{C}$ with labeled DNA from: } \\
\hline & & Strain $\mathrm{W}^{\mathrm{T}}$ & Strain DE30 & Strain DS27 & Strain AG & Strain LL & Strain $\mathrm{X} 14^{\mathrm{T}}$ \\
\hline \multicolumn{8}{|l|}{ Genomic species 1 ( $N$. winogradskyi) } \\
\hline \multicolumn{8}{|l|}{ Subspecies la } \\
\hline $\mathrm{W}^{\mathrm{T}}\left(=\right.$ ATCC $\left.25391^{\mathrm{T}}\right)$ & 60 & $100^{a}$ & $65(4)^{b}$ & 53 & $59(3)$ & $35(11)$ & 26 \\
\hline B1 & $-c$ & 83 & 47 & - & - & 45 & - \\
\hline WBD1 & - & 84 & 67 & - & 55 & - & - \\
\hline WM1 & 58 & 75 & - & - & - & 36 & - \\
\hline LM1 & 60 & 83 & - & - & - & - & - \\
\hline LM2 & - & 85 & - & - & - & 44 & - \\
\hline DE2 & - & 71 & 54 & - & - & - & - \\
\hline DE11 & 61 & $88(1)$ & $57(5.5)$ & 47 & $53(5)$ & $40(8.5)$ & 24 \\
\hline \multicolumn{8}{|l|}{ Subspecies $1 b$} \\
\hline $6 \mathrm{R}$ & 61 & $55(5)$ & $90(1)$ & 86 & $51(4.5)$ & $36(8)$ & 27 \\
\hline DE3 & - & $58(5.5)$ & 100 & - & 49 & 46 & 30 \\
\hline DE10 & - & 50 & 96 & - & - & $38(11)$ & - \\
\hline DE23 & - & 58 & 100 & - & 52 & 47 & 27 \\
\hline DE30 & 61 & $53(5.5)$ & 100 & 101 & $51(5)$ & 38 (11.5) & 26 \\
\hline DS27 & - & 57 & - & 100 & - & 34 & - \\
\hline DS30 & 60 & $53(6)$ & 100 & - & - & 35 & 31 \\
\hline $\begin{array}{l}\text { Subspecies 1c strain AG } \\
\text { (= ATCC 14123) }\end{array}$ & 60 & $59(5)$ & $62(5)$ & 62 & 100 & $40(9)$ & 26 \\
\hline \multicolumn{8}{|l|}{ Genomic species 2} \\
\hline LL & 59 & 33 & 40 & 32 & 28 & 100 & 28 \\
\hline DS13 & - & - & - & - & 32 & 70 & - \\
\hline DS17 & 59 & 33 & 38 & - & 31 & 73 & 26 \\
\hline DS28 & - & 31 & - & - & - & $62(3)$ & - \\
\hline $\mathrm{DS}^{\prime} 16$ & 58 & 34 & - & - & - & 62 & - \\
\hline $\begin{array}{l}\text { Genomic species } 3 \text { ( } N . \text { hamburgensis) } \\
\text { strain X14 }\end{array}$ & 61 & 30 & 30 & 23 & 22 & 31 & 100 \\
\hline
\end{tabular}

${ }^{a}$ Level of relatedness at $70^{\circ} \mathrm{C}$

${ }^{b}$ The numbers in parentheses are $\Delta T_{m}$ values (in degrees Celsius).

$c$, no data.

The patterns associated with each strain are shown in Table 3. Strains which produced EcoRV pattern E1 produced one of four MluI patterns (pattern M1, M2, M3, or M4). Strains which produced $M l u I$ pattern M5 produced one of two EcoRV patterns (pattern E2 or E3). Strain X14 ${ }^{\mathrm{T}}$ produced specific patterns with the two enzymes (patterns E4 and M6).

Our results suggest that only one copy of the rRNA operon is present in the Nitrobacter chromosome. This

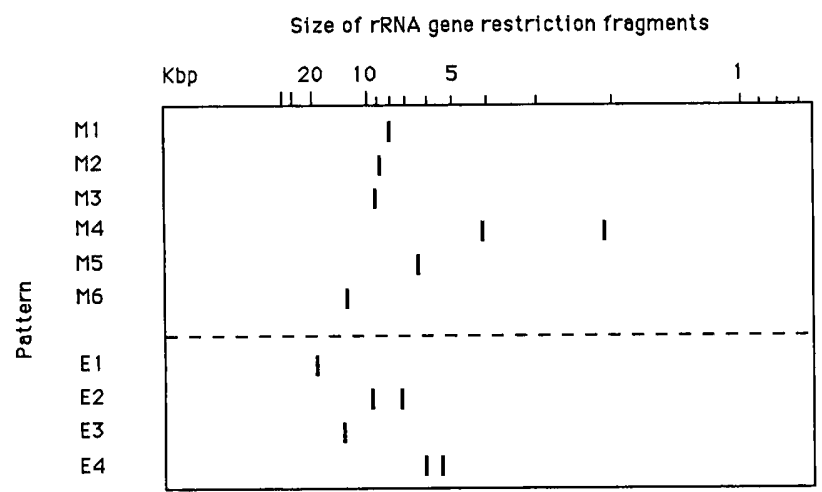

FIG. 1. Normalized graph showing migration patterns of rRNA gene restriction fragments after cleavage by $M l u \mathbf{I}$ (patterns $\mathrm{M} 1$ to M6) or EcoRV (patterns E1 to E4) and hybridization with labeled $E$. coli $16+23 \mathrm{~S}$ rRNA. agrees with the concept that there is a correlation between the number of operons and the growth rate (16).

Serotyping. Nine Nitrobacter strains were examined serologically by using the indirect immunofluorescence technique. These strains fell into five serogroups (Table 4). Strain $\mathrm{W}^{\dagger}$, WBD1, and WM1 belonged to serogroup $N$. winogradskyi of Stanley and Schmidt (42). Serogroup LL contained three strains (strains LL, LM1, and LM2). Strains DE2 and DE11 belonged to the same serogroup. Another serogroup contained a single strain, strain AG.

\section{DISCUSSION}

The $\mathrm{G}+\mathrm{C}$ contents of the Nitrobacter DNAs (58 to 61 mol\%) agreed with the range of values reported previously $(5,46)$.

It is currently accepted that a species includes strains that exhibit approximately $70 \%$ or greater DNA-DNA relatedness and have $\Delta T_{m}$ values of less than $5^{\circ} \mathrm{C}(48) . \Delta T_{m}$ values are important since they are less subject to variation because of genome size or methodological choice (17). Strains that have $\Delta T_{m}$ values of 3 to $5^{\circ} \mathrm{C}$ often belong to different subspecies within a species (17). Thus, our DNA hybridization results led us to delineate three species and to split genomic species 1 into three genomic subspecies (Table 2).

Genomic species 1 corresponds to $N$. winogradskyi since it contains the type strain of this species, strain W (= ATCC 25391) (37). A total of 15 other strains were grouped in this species. All of the strains in this species produced the same EcoRV rRNA gene restriction pattern. This species con- 


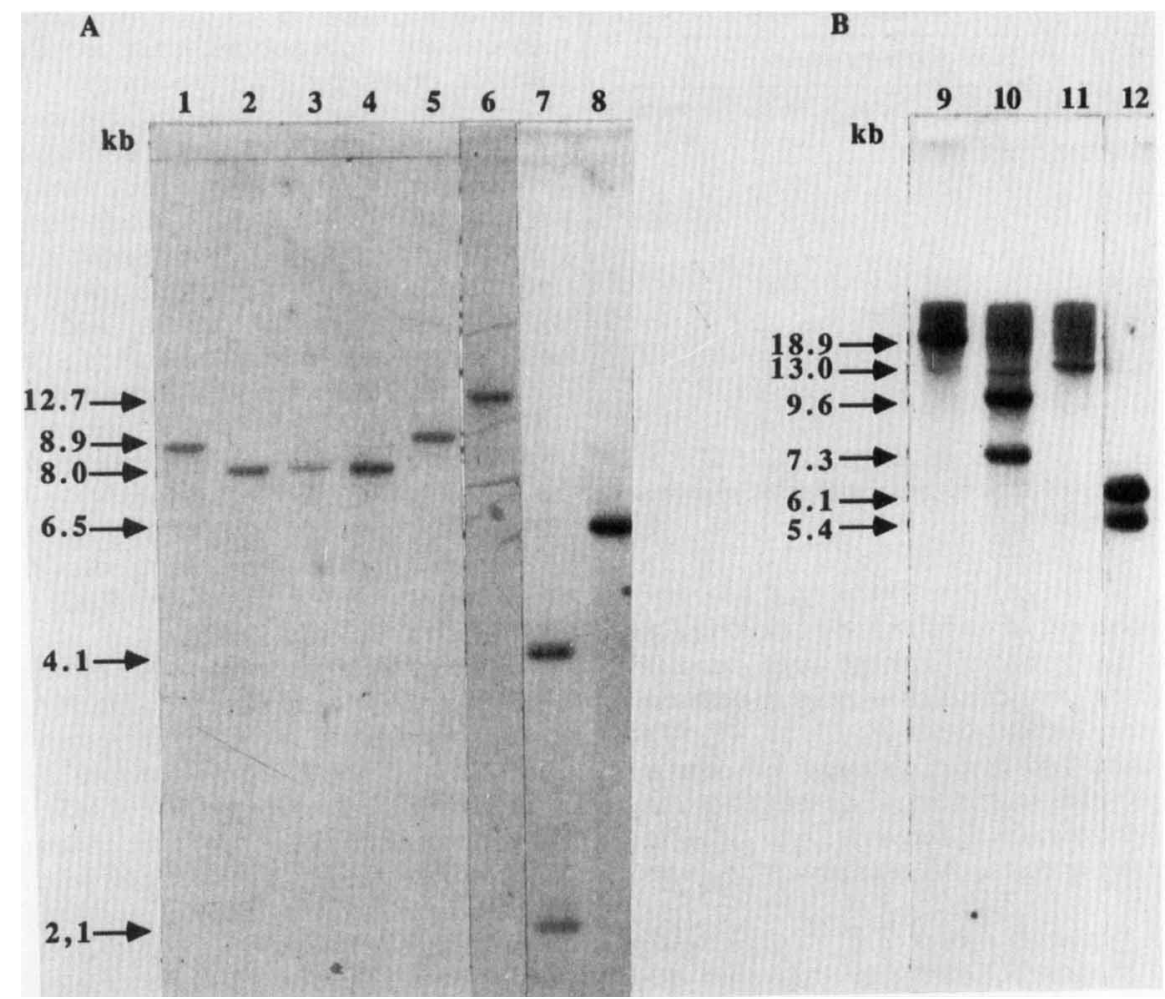

FIG. 2. rRNA restriction patterns of Nitrobacter DNAs cleaved by MluI (A) or EcoRV (B). Lane 1, strain WBD1; lane 2, strain B1; lane 3, strain WM2; lane 4, strain LM2; lane 5, strain DE11; lane 6, strain X14 ${ }^{\mathrm{T}}$; lane 7, strain 6R; lane 8, strain LL; lane 9, strain DS30; lane 10, strain LL; lane 11, strain DS28; lane 12, strain X14 ${ }^{\mathrm{T}}$.

tained three subspecies, which were 47 to $67 \%$ related $\left(\Delta T_{m}\right.$ values, 3 to $6^{\circ} \mathrm{C}$ ).

Subspecies la contained eight closely related strains (strains $\mathrm{W}^{\mathrm{T}}$, B1, WBD1, WM1, LM1, LM2, DE2, and DE11), as shown by DNA relatedness values (Table 2). However, some heterogeneity in MluI rRNA gene polymorphism was observed (Table 3 ). Subspecies la contained type strain ATCC 25391 of $N$. winogradskyi (37).

Subspecies $1 \mathrm{~b}$ contained seven closely related strains (strains 6R, DE3, DE10, DE23, DE30, DS27, and DS30), which were 47 to $67 \%$ related to subspecies 1a strains. The homogeneity of this DNA genomic group was shown by the single $M l u I$ rRNA pattern (Table 3 ). Subspecies $1 b$ differed from subspecies la in MluI rRNA gene restriction pattern (Table 3). Strain $6 \mathrm{R}$ is proposed as the reference strain for subspecies $1 \mathrm{~b}$.

Strain AG was the only representative of subspecies 1c. This strain could not be differentiated from subspecies 1a strains on the basis of polymorphism of rRNA genes by using the two restriction enzymes. Strain AG (= ATCC 14123 ) is a reference strain of " $N$. agilis" (1). " $N$. agilis" did not appear on the Approved Lists of Bacterial Names (37). Our data suggested that " $N$. agilis" may be a subspecies of $N$. winogradskyi, although there are few phenotypic traits to support this hypothesis.

From 1931 to 1974 , all motile Nitrobacter strains were named " $N$. agilis" (26). This name appeared in Bergey's Manual of Determinative Bacteriology, 7th ed. (7). It has been demonstrated that the motility of Nitrobacter strains varies with the growth phase $(40,47)$. Moreover, $N$. winogradskyi and " $N$. agilis" could not be differentiated on
TABLE 3. Results obtained with different approaches

\begin{tabular}{|c|c|c|c|c|c|}
\hline \multirow{2}{*}{ Strain } & \multirow{2}{*}{$\begin{array}{l}\text { Sero- } \\
\text { group }\end{array}$} & \multirow{2}{*}{$\begin{array}{c}\mathrm{G}+\mathrm{C} \\
\text { content } \\
\text { (mol\%) }\end{array}$} & \multirow{2}{*}{ Genomic group } & \multicolumn{2}{|c|}{$\begin{array}{l}\text { rRNA gene } \\
\text { polymorphism }\end{array}$} \\
\hline & & & & $\begin{array}{c}M l u \mathrm{I} \\
\text { pattern }\end{array}$ & $\begin{array}{l}\text { EcoRV } \\
\text { pattern }\end{array}$ \\
\hline $\mathrm{W}^{\mathrm{T}}$ & $w$ & 60 & Subspecies 1a & M1 & E1 \\
\hline B1 & $\mathrm{W}^{b}$ & & Subspecies la & M1 & E1 \\
\hline WBD1 & W & & Subspecies la & M2 & E1 \\
\hline WM1 & W & 58 & Subspecies 1a & M1 & E1 \\
\hline LM1 & $\mathrm{L}$ & 60 & Subspecies 1a & M1 & E1 \\
\hline LM2 & $\mathrm{L}$ & & Subspecies 1a & M1 & E1 \\
\hline DE2 & DE11 & & Subspecies 1a & M3 & E1 \\
\hline DE11 & DE11 & 61 & Subspecies 1a & M3 & E1 \\
\hline $\mathrm{AG}$ & AG & 60 & Subspecies 1c & M1 & E1 \\
\hline $6 \mathrm{R}$ & $6 \mathrm{R}^{b}$ & 61 & Subspecies $1 \mathrm{~b}$ & M4 & E1 \\
\hline DE3 & & & Subspecies 1b & M4 & E1 \\
\hline DE10 & & & Subspecies $1 b$ & M4 & E1 \\
\hline DE23 & & & Subspecies $1 b$ & M4 & E1 \\
\hline DE30 & & 61 & Subspecies $1 b$ & M4 & E1 \\
\hline DS27 & & & Subspecies 1b & M4 & E1 \\
\hline DS30 & & 60 & Subspecies $1 \mathrm{~b}$ & M4 & E1 \\
\hline LL & $\mathbf{L}$ & 59 & Genomic species 2 & M5 & E2 \\
\hline DS13 & & & Genomic species 2 & M5 & E3 \\
\hline DS17 & & 59 & Genomic species 2 & M5 & E3 \\
\hline DS28 & & & Genomic species 2 & M5 & E3 \\
\hline DS'16 & & 58 & Genomic species 2 & M5 & E3 \\
\hline $\mathrm{X} 14^{\mathrm{T}}$ & $\mathrm{X} 14^{c}$ & 61 & Genomic species 3 & M6 & E4 \\
\hline
\end{tabular}

$a$ Pattern associated with each strain.

${ }^{b}$ See reference 42 .

${ }^{c}$ See reference 5 . 
TABLE 4. Cross-reactivity of Nitrobacter strains

\begin{tabular}{lllccc}
\hline \multirow{2}{*}{$\begin{array}{c}\text { Nitrobacter } \\
\text { strain }\end{array}$} & Genomic group & \multicolumn{6}{c}{ Cross-reactivity with antiserum to: } \\
\cline { 3 - 6 } & & $\begin{array}{c}\text { Strain } \\
\text { W }^{\mathrm{T}}\end{array}$ & $\begin{array}{c}\text { Strain } \\
\text { LL }\end{array}$ & $\begin{array}{c}\text { Strain } \\
\text { AG }\end{array}$ & $\begin{array}{c}\text { Strain } \\
\text { DE11 }\end{array}$ \\
\hline W $^{\mathrm{T}}$ & Subspecies 1a & $4+^{a}$ & - & - & \\
WBD1 & Subspecies 1a & $3+$ & $(+)$ & & \\
WM1 & Subspecies 1a & $3+$ & - & & \\
LL & Genomic species 2 & - & $4+$ & $(+)$ & \\
LM1 & Subspecies 1a & - & $3+$ & & \\
LM2 & Subspecies 1a & - & $3+$ & & \\
AG & Subspecies 1c & - & - & $4+$ & \\
DE2 & Subspecies 1a & - & - & $(+)$ & $4+$ \\
DE11 & Subspecies 1a & - & - & $(+)$ & $4+$ \\
\hline
\end{tabular}

$a-$, no fluorescence; $(+)$, bacteria visible but not distinct; $3+$, moderate fluorescence; $4+$, maximum fluorescence.

the basis of DNA G+C content or cellular fatty acid content $(2,46)$, and studies on the growth of these organisms in presence of organic matter gave conflicting results because of the diversity of the strains compared $(22,27,38,43,47)$. Pan (27) could not separate " $N$. agilis" from $N$. winogradskyi by using phenotypic characteristics. Consequently, in Bergey's Manual of Determinative Bacteriology, 8th ed. (44), a single Nitrobacter species, $N$. winogradskyi, was included.

Strains belonging to genomic group 2 (Table 2) were clearly separated from strains belonging to the other genomic groups, as shown by DNA relatedness and $\Delta T_{m}$ values (Table 2 ). These strains constituted a new, separate genomic species (genomic species 2). Our results were confirmed by rRNA gene polymorphism data (Table 3 ). Previous data on the physiology, serology, and protein contents $(13,14,19 a, 21,24)$ of strains $\mathrm{W}^{\mathrm{T}}$ and $\mathrm{LL}$ showed that these two strains differ considerably. Strains, DS13, DS17, DS28, and DS'16, which belong to genomic species 2, were indistinguishable as determined by rRNA polymorphism (Table 3), polymorphism of the intergenic spacer region of the ribosomal operon (25), and restriction length polymorphism of the total DNA (data not shown). These data led us to believe that strains DS28 and DS'16 are members of genomic species 2 , even though they exhibited only $62 \%$ DNA-DNA homology with strain LL. Among the genomic species 2 strains, strain LL produced a specific EcoRV rRNA restriction pattern.

In this study we did not include " $N$. vulgaris," a species described by Bock et al. (5), since our experimental work was finished when the strains of this species were received and it was not practical to cultivate them given the long time necessary. Nevertheless, clear physiological differences led us to separate " $N$. vulgaris" from genomic species 2 . "N. vulgaris" strains often grow more slowly under lithoautotrophic conditions than under chemoorganotrophic conditions (5). In contrast, strain LL, a member of genomic species 2 , grew better under lithoautotrophic conditions (14).

Genomic species 3 corresponds to $N$. hamburgensis since it contains the type strain of this species (strain X14) $(6,45)$. As expected, this species was not closely related to $N$. winogradskyi and to genomic species 2 (Table 2). Strain $\mathrm{X} 14^{\mathrm{T}}$ produced a specific rRNA pattern with each of the enzymes which we used (Table 3 ). Thus, we confirmed with these results the status of $N$. hamburgensis as a species.

Serotyping by using the immunofluorescence technique was the first method that was used to characterize Nitrobac- ter strains, and this method has remained the reference method since phenotypic data for these slowly growing bacteria are often difficult to obtain. Nevertheless, the level of discrimination of serotyping has not been clearly established yet. Bock et al. (5) found concurrent results when they used serology and DNA-DNA homology to study $N$. winogradskyi, $N$. hamburgensis, and " $N$. vulgaris." In contrast, our results did not show a clear correlation between serogroups and genomic groups. Diverse serogroups were found in subspecies 1a, and cross-reactions were observed between strains belonging to two different genomic species ( $N$. winogradskyi and genomic species 2) (Table 3 ).

Strains obtained from widely separated geographical areas were found to be very closely related in our study, whereas strains which coexist in the same lake belonged to different genomic species. It seems that geographical origin has little bearing on the genetic properties of Nitrobacter strains, and this may be related to the presence of locally coexisting ecological niches.

In conclusion, we propose a new taxonomic scheme for the genus Nitrobacter based on DNA relatedness and rRNA gene polymorphism. We delineated three genomic species. Genomic species 1 , corresponding to the previously described species $N$. winogradskyi (45), was split into three subspecies. This is the first time that subspecies have been described for $N$. winogradskyi. As previously noted (45), $N$. winogradskyi strains differed genotypically, but no clear correlation was found with phenotypic characteristics. Genomic species 2, which has not been described previously, was distinct from $N$. winogradskyi and $N$. hamburgensis; strain LL is proposed as the reference strain of this taxon. We confirmed that genomic species 3 , which corresponds to $N$. hamburgensis, is distantly related to the other genomic groups.

Because of the extremely slow growth of Nitrobacter isolates, phenotypic tests are not always discriminating enough for identification purposes. In agreement with the recommendations published previously by a group of experts (48), the new subspecies and genomic species cannot be named at this time.

\section{ACKNOWLEDGMENTS}

We thank D. Bernillon and M. Lefèvre for technical assistance, L. Gay for scintillation counting, $H$. Meugnier for the use of the Merck-Hitachi chromatography system, and P. A. D. Grimont for critically reading the manuscript.

\section{REFERENCES}

1. American Type Culture Collection. 1989. Catalogue of bacteria and bacteriophage. 17th ed. American Type Culture Collection, Rockville, Md.

2. Auran, T. B., and E. L. Schmidt. 1972. Similarities between Hyphomicrobium and Nitrobacter with respect to fatty acids. J. Bacteriol. 109:450-451.

3. Belser, L. W. 1979. Population ecology of nitrifying bacteria. Annu. Rev. Microbiol. 33:309-333.

4. Belser, L. W., and E. L. Schmidt. 1978. Serological diversity within a terrestrial ammonia-oxydizing population. Appl. Environ. Microbiol. 36:589-593.

5. Bock, E., H.-P. Koops, U. C. Möller, and M. Rudert. 1990. A new facultatively nitrite oxidizing bacterium, Nitrobacter vulgaris sp. nov. Arch. Microbiol. 153:105-110.

6. Bock, E., H. Sundermeyer-Klinger, and E. Stackebrandt. 1983. New facultative lithotrophic nitrite-oxidizing bacteria. Arch. Microbiol. 136:281-284. 
7. Breed, R. S., E. G. D. Murray, and N. R. Smith (ed.). 1957. Bergey's manual of determinative bacteriology, 7th ed., p. 1094. The Williams \& Wilkins Co., Baltimore.

8. Brenner, D. J., A. C. McWorter, J. K. Leete Knutson, and A. G. Steigerwalt. 1982. Escherichia vulneris: a new species of Enterobacteriaceae associated with human wounds. J. Clin. Microbiol. 15:1133-1140.

9. Crosa, J. M., D. J. Brenner, and S. Falkow. 1973. Use of a single-strand-specific nuclease for analysis of bacterial and plasmid deoxyribonucleic acid homo- and heteroduplexes. J. Bacteriol. 115:904-911.

10. Fernandez, M. P., H. Meugnier, P. A. D. Grimont, and R. Bardin. 1989. Deoxyribonucleic acid reladness among members of the genus Frankia. Int. J. Syst. Bacteriol. 40:424-429.

11. Fliermans, C. B., B. B. Bohlool, and E. L. Schmidt. 1974. Autecological study of chemoautotroph Nitrobacter by immunofluorescence. Appl. Microbiol. 27:124-129.

12. Freitag, A., M. Rudert, and E. Bock. 1987. Growth of Nitrobacter by dissimilatory nitrate reduction. FEMS Microbiol. Lett. 48:105-109.

13. Gay, G., and A. Corman. 1984. Comparative study of the growth of two strains of Nitrobacter in batch and continuous culture. Microb. Ecol. 10:99-105.

14. Gay, G., A. Josserand, and R. Bardin. 1983. Growth of two serotypes of Nitrobacter in mixotrophic and chemoorganotrophic conditions. Can. J. Microbiol. 29:394-397.

14a.Grimont, F. Unpublished data.

15. Grimont, F., and P. A. D. Grimont. 1986. Ribosomal ribonucleic acid gene restriction patterns as potential taxonomic tools. Ann. Inst. Pasteur/Microbiol. (Paris) 137B:165-175.

16. Grimont, F., and P. A. D. Grimont. 1990. La carte d'identité génétique des bactéries. Biofutur 95:50-52.

17. Grimont, P. A. D. 1988. Use of DNA reassociation in bacterial classification. Can. J. Microbiol. 34:541-546.

18. Grimont, P. A. D., M. Y. Popoff, F. Grimont, C. Coynault, and M. Lemelin. 1980. Reproducibility and correlation study of three deoxyribonucleic acid hybridization procedures. Curr. Microbiol. 4:325-330.

19. Irino, K., F. Grimont, I. Casin, P. A. D. Grimont, and The Brazilian Purpuric Fever Study Group. 1988. rRNA gene restriction patterns of Haemophilus influenzae biogroup aegyptius strains associated with Brazilian purpuric fever. J. Clin. Microbiol. 26:1535-1538.

19a.Josserand, A. 1983. Ph.D. thesis. Université Lyon I, Villeurbanne, France.

20. Josserand, A., and R. Bardin. 1981. Nitrification en sol acide. I. Mise en évidence de germes autotrophes nitrifiants (genre Nitrobacter) dans un sol forestier sous resineux. Rev. Ecol. Biol. Sol 18:435-445.

21. Josserand, A., and J. C. Cleyet-Marel. 1979. Isolation from soils of Nitrobacter and evidence for novel serotypes using immunofluorescence. Microb. Ecol. 5:207-213.

22. Kalthoff, H., S. Fehr, H. Sundermeyer, L. Renwrantz, and E. Bock. 1979. A comparison by means of antisera and lectins of surface structures of Nitrobacter winogradskyi and $N$. agilis. Curr. Microbiol. 2:375-380.

23. MacDonald, R. M. 1986. Nitrification in soil: introductory history, p. 17-38. In J. I. Prosser (ed.), Nitrification. SGM IRL Press, Oxford.

24. Navarro, E., A. Josserand, B. Bernillon, and R. Bardin. 1987. Aspects microbiens de la nitrification: effects des variations quantitatives et diversité des souches de Nitrobacter. Rev. Ecol. Biol. Sol 24:591-602.

25. Navarro, E., P. Simonet, P. Normand, and R. Bardin. 1992. Characterization of natural population of Nitrobacter spp. using PCR/RFLP analysis of the ribosomal intergenic spacer. Arch. Microbiol. 157:107-115.

26. Nelson, D. H. 1931. Isolation and characterization of Nitrosomonas and Nitrobacter. Zentralbl. Bakteriol. Parasitenkd. Infektionskr. Abt. 2 83:280-311.

27. Pan, P. H. C. 1971. Lack of distinction between Nitrobacter agilis and Nitrobacter winogradskyi. J. Bacteriol. 108:14161418.
28. Peyret, M., J. Freney, H. Meugnier, and J. Fleurette. 1989. Determination of $G+C$ content of DNA using high-performance liquid chromatography for the identification of staphylococci and micrococci. Res. Microbiol. 140:467-475.

29. Prosser, J. I., and D. J. Cox. 1982. Nitrification, p. 178-193. In R. G. Burns and J. H. Slater (ed.), Experimental microbial ecology. Blackwell Scientific Publications, Oxford.

30. Rigby, P. W. J., M. Dieckmann, C. Rhodes, and P. Berg. 1977. Labelling deoxyribonucleic acid to high specific activity in vitro by nick translation with DNA polymerase I. Int. J. Syst. Bacteriol. 113:237-251.

31. Robert, F. M., and E. L. Schmidt. 1985. Somatic serogroups among 55 strains of Rhizobium phaseoli. Can. J. Microbiol. 31:519-523.

32. Schaffer, H. E., and R. R. Sederoff. 1981. Improved estimation of DNA fragment length from agarose gels. Anal. Biochem. 115:113-122.

33. Schmidt, E. L., and L. W. Belser. 1982. Nitrifying bacteria, p. 1027-1042. In R. H. Miller and D. R. Keeney (ed.), Methods of soil analysis, 2nd ed. American Society of Agronomists, Madison, Wis.

34. Schmidt, E. L., J. A. E. Molina, and C. Chiang. 1973. Isolation of chemoautotrophic nitrifiers from Moroccan soils. Bull. Ecol. Res. Comm. (Stockholm) 17:166-167.

35. Seewaldt, E., K. H. Schleifer, E. Bock, and E. Stackebrandt. 1982. The close phylogenetic relationship of Nitrobacter and Rhodopseudomonas palustris. Arch. Microbiol. 131:287-290.

36. Simonet, P., A. Capellano, E. Navarro, R. Bardin, and A. Moiroud. 1984. An improved method for lysis of Frankia with achromopeptidase allows detection of new plasmid. Can. J. Microbiol. 30:1292-1295.

37. Skerman, V. B. D., V. McGowan, and P. H. A. Sneath (ed.). 1980. Approved lists of bacterial names. Int. J. Syst. Bacteriol. 30:225-420.

38. Smith, A. J., and D. S. Hoare. 1968. Acetate assimilation by Nitrobacter agilis in relation to its "obligate autotrophy." J. Bacteriol. 95:844-855.

39. Soriano, S., and N. Walker. 1968. Isolation of ammonia oxidizing autotrophic bacteria. J. Appl. Bacteriol. 31:493-498.

40. Soriano, S., and N. Walker. 1973. The nitrifying bacteria in soils from Rothamsted classical fields and elsewhere. J. Appl. Bacteriol. 36:523-529.

41. Stackebrandt, E., R. G. E. Murray, and H. G. Trüper. 1988. Proteobacteria classis nov., a name for the phylogenetic taxon that includes the "purple bacteria and their relatives." Int. J. Syst. Bacteriol. 38:321-325.

42. Stanley, P. M., and E. L. Schmidt. 1981. Serological diversity of Nitrobacter spp. from soil and aquatic habitats. Appl. Environ. Microbiol. 41:1069-1071.

43. Steinmüller, W., and E. Bock. 1976. Growth of Nitrobacter in the presence of organic matter. I. Mixotrophic growth. Arch. Microbiol. 108:299-304.

44. Watson, S. W. 1974. Family I. Nitrobacteraceae, p. 450-456. In R. E. Buchanan and N. E. Gibbons (ed.), Bergey's manual of determinative bacteriology, 8th ed. The Williams \& Wilkins Co., Baltimore.

45. Watson, S. W., E. Bock, H. Harms, H.-P. Koops, and A. B. Hooper. 1989. Nitrifying bacteria, p. 1808-1834. In J. C. Holt, J. T. Staley, M. P. Bryant and N. Pfenning (ed.), Bergey's manual of systematic bacteriology, vol. 3. The Williams \& Wilkins Co., Baltimore.

46. Watson, S. W., and M. Mandel. 1971. Comparison of the morphology and deoxyribonucleic acid composition of 27 strains of nitrifying bacteria. J. Bacteriol. 107:563-569.

47. Watson, S. W., and J. B. Waterbury. 1971. Characteristics of two marine nitrite oxidizing bacteria, Nitrospina gracilis nov. gen. nov. sp. and Nitrococcus mobilis nov. gen. nov. sp. Arch. Mikrobiol. 77:203-230.

48. Wayne, L. G., D. J. Brenner, R. R. Colwell, P. A. D. Grimont, O. Kandler, M. I. Krichevsky, L. H. Moore, W. E. C. Moore, R. G. E. Murray, E. Stackebrandt, M. P. Starr, and H. G. Trüper. 1987. Report of the Ad Hoc Committee on Reconciliation of Approaches to Bacterial Systematics. Int. J. Syst. 
Bacteriol. 34:463-464.

49. Winogradsky, S. 1892. Contributions à la morphologie des organismes de la nitrification. Arch. Sci. Biol. St. Petersb. 1:88-137.

50. Woese, C. R., E. Stackebrandt, W. G. Weisburg, B. J. Paster, M. T. Madigan, V. J. Fowler, C. M. Hahn, P. Blanz, R. Gupta, K. H. Nealson, and G. E. Fox. 1984. The phylogeny of purple bacteria: the alpha subdivision. Syst. Appl. Microbiol. 5:315-
326.

51. Woldendorp, J. W., and H. J. Laanbroek. 1989. Activity of nitrifiers in relation to nitrogen nutrition of plants in natural ecosystems. Plant Soil 115:217-228.

52. Wood, P. M. 1986. Nitrification as a bacterial energy source, p. 39-62. In J. I. Prosser (ed.), Nitrification. SGM IRL Press, Oxford. 